\title{
A visual indicator of the physiological maturity stage of indeterminate dry beans'
}

\author{
Jonathan Cerna and James S. Beaver
}

\begin{abstract}
Two indeterminate breeding lines, 1-227 and RAB 205, were planted during two growing seasons for the purpose of identifying a visual indicator of physiological maturity of dry beans which could be used in the field. Ten-plant samples were taken at 2-day intervals beginning approximately $\mathbf{8}$ weeks after emergence to determine seed dry weight accumulation and number of green, yellow, and brown pods. In order to identify a stage of pod development which coincided with maximum accumulation of seed dry weight, the number of green, yellow and brown pods per plant was estimated with polinomial regression equations. Coefficients of determination for the number of yellow pods were relatively low, ranging from 0.52 to 0.77 , whereas the coefficients of determination for most equations for green and brown pod numbers were near 0.9 , indicating that the number of both green and brown pods may be useful as indicators of the occurrence of physiological maturity. Physiological maturity of L-227 occurred when plants had developed 1 to 2 green pods and 12 to 14 brown pods, whereas physiological maturity of RAB 205 occurred when 2 green pods and 8 brown pods were present on each plant. In the field, the number of green pods would be a better visual indicator of physiological maturity than the number of brown pods because fewer green pods have to be counted and because the green pods are on top of the plant.
\end{abstract}

\section{RESUMEN}

Un indicador visual de la madurez fisiológica de habichuelas de inflorescencia indeterminada

Dos líneas indeterminadas de habichuela, L-227 y RAB 205, se sembraron en dos estaciones del año para identificar un indicador visual de la etapa de madurez fisiológica que pudiera usarse en el campo. Muestras de 10 plantas se tomaron cada 2 días para determinar la acumulación de materia seca en el grano y el número de vainas verdes, amarillas y secas. Se usaron ecuaciones de regresión lineales, cuadráticas y cúbicas para deferminar el número de vainas verdes, amarillas y secas que coincidian con el punto de máxima acumulación de peso seco en el grano. Los coeficientes de determinación para el número de vainas amarillas fueron relativamente bajos; variaron de 0.52 a 0.77 . Por otro lado, la mayoría de los coeficientes de determinación para las ecuaciones del número de vainas

'Manuscript submitted to the Editorial Board 5 June 1989. This research was supported by Title XII Bean/Cowpea CRSP of the U.S. Agency for International Development under Grant No. AID/DSAN/XII-G-0261.

${ }^{2}$ Former graduate student (now graduate student in agronomy, Iowa State University)

${ }^{3}$ Associate professor, Dept. Agron. and Soils. 
verdes y de secas fueron cercanos a 0.9 , lo que indica que tanto el número de vainas verdes como el de vainas secas podían ser buenos indicadores de madurez fisiológica. La madurez fisiológica de 1-227 ocurrió cuando a las plantas les quedaban de 1 a 2 vainas verdes y tenían de 12 a 14 vainas secas. La madurez fisiológica de RAB 205 ocurrió cuando las plantas tenían 2 vainas verdes y 8 vainas secas. Estos resultados indican que el número de vainas verdes, en condiciones de campo, podría ser un mejor indicador de la madurez fisiológica que el número de vainas secas, no solamente porque habría menos vainas verdes que contar, sino porque las verdes estarian en la parte superior de la planta.

\section{INTRODUC'TION}

Physiological maturity (PM) is a term used by agronomists to define the stage of development beyond which there is no further increase in dry weight, or to denote maximum dry matter accumulation in the grain or seed. A precise determination of PM is of interest because it permits a more precise measure of the duration of the seed filling period.

Physiological maturity of maize (Zea may L.), (3), (1969) and sorghum [Sorghum bicolor (L.) Moench](4), can be identified in the field by a visible dark layer in the placental region of the kernels. The first appearance of brown (mature) pods (growth stage R7) was suggested by Fehr and Caviness (5) as an acceptable estimate of PM of soybeans (Glycine $\max$ L. [Merr.]) on a field basis. A similar visual indicator for determining the PM of dry beans (Phaseolus vulgaris L.) has not been reported.

Accurate descriptions of stages of development of the dry beans should facilitate the comparison of results from different bean research projects. Lebaron (10) noted that the system of developmental stages described for soybeans by Fehr et al. (5) works well for dry beans, lima bean (Phaseolus lunatus L.), and southern pea (Vigna unguiculata L.). He described dry bean PM (R8) as the stage of development when leaves yellowed over half of plant, when very few small new pods/blossom were developing, and pods were drying. Researchers from CIAT (2) described a general stage of maturation (R9) which begins when the first pod loses its green color. This system is similar to the one previously suggested by Fehr and Caviness for soybeans (6). Other bean researchers $(8,11)$ have defined PM as the stage of develpment when about $90 \%$ of the total number of pods have turned yellow. In an attempt to relate visual changes of pod or seeds to maximum seed dry weight accumulation in the bean fruit, Garner ( 7 ) followed color changes in the seed coat, the cotyledons, the embryo, the funiculus, and the pod. His data suggested that embryo color was the best criterion of PM of individual dry bean seeds. This visual indicator, however, was not found to be reliable in a community of plants. The objective of this research was to identify a specific visual indicator of PM of dry beans which could be used in the field. 


\section{MATERIALS AND METHODS}

The study was conducted at the Isabela Research Substation, Isabela, Puerto Rico, during two growing seasons in 1988 on a well-drained Coto (Tropeptic Haplorthox, clayey, kaolinitic, isohyperthermic) soil. Two indeterminate breeding lines were used in the study. Line 'L-227' has a IIA growth habit and small white seeds, and 'RAB 205 ' has a IIB growth habit and small red seeds. Both IIA and IIB growth habits are common for small-seeded beans (1). The two lines were planted in unreplicated plots 20 January and 5 May 1988. Each plot had 105 -m rows spaced 0.5 $\mathrm{m}$ apart. The seeding rate was 240,000 seeds/ha.

Ten-plant samples to determine seed dry weight were randomly taken from each plot, beginning 57 days after emergence for the first planting and 55 days after emergence for the second planting. Once initiated, samples were taken at 2-day intervals until plants had reached harvest maturity (at least $95 \%$ of the pods had turned brown). On each sampling date all pods containing at least one seed were classified as green, yellow, or brown (dry), and counted. Seeds were removed from the pods and both fresh and dry weights were recorded. The latter was measured after drying the seed for 48 hours at $55^{\circ} \mathrm{C}$ to a constant moisture.

The patterns of accumulation of seed dry weight were determined with quadratic regression ( $Y=\hat{a}+b_{1} x_{1}+b_{2} x_{2}{ }^{2}$ ) equations (9) in which seed dry weight was the dependent variable $(X)$ and days after emergence was the independent variable $(X)$. The maximum point of dry matter accumulation was determined by calculating the first derivative of the quadratic regression equation. In order to identify a stage of pod development which coincided with maximum accumulation of seed dry weight, the number of green, yellow and brown pods was estimated with linear, quadratic, and cubic regression equations, where the number of green, yellow and brown pods were the independent variables and days after emergence was the independent variable. The polinomial equation which provided the best fit was determined by $F$ tests.

\section{RESULTS AND DISCUSSION}

The large coefficients of determination indicated that quadratic equations provided an adequate fit for seed weight accumulation (table 1). Both genotypes flowered and reached PM earlier in the May planting, when temperatures were higher. RAB 205 reached PM 1 day earlier than L-227 in the January planting date, and 2 days earlier than L-227 in the May planting date (table 1). L-227 reached PM when the seeds contained an average of 47 and $51 \%$ moisture in the January and May plantings, respectively, whereas PM of RAB 205 occurred when the seeds contained 43 and $58 \%$ of moisture in the January and May plantings, respectively. 
TABLE 1.-Estimated number of days from emergence to physiological maturity and coefficients of determination of quadratic regression equations for seed veight accumulation of two bean genotypes planted in two seasons in Puerto Rico

\begin{tabular}{lccc}
\hline Genotype & $\begin{array}{c}\text { Planting } \\
\text { date }\end{array}$ & $\begin{array}{c}\text { Days to } \\
\text { physiological } \\
\text { maturity }\end{array}$ & $\begin{array}{c}\text { Coefficients of } \\
\text { determination }\end{array}$ \\
\hline L227 & January & 74 & 0.94 \\
RAB 205 & May & 68 & 0.83 \\
& January & 73 & 0.98 \\
& May & 66 & 0.92 \\
\hline
\end{tabular}

Quadratic equations provided the best fit for the yellow pod data. Nevertheless, coefficients of determination for the number of yellow pods were fairly low, ranging from 0.52 to 0.77 (table 2). Several researchers $(2,8,10,11)$ have mentioned the presence of yellow pods as a good indicator of PM. These results, however, suggest that the trait was too variable to be used as a reliable visual indicator. On the other hand, most of the coefficients of determination for the equations for gxeen and brown pod numbers were near $90 \%$ (table 2). The number of green pods decreased, whereas brown pods increased linearly as PM approached. Therefore, both the number of green and brown pods may be useful as indicators of the occurrence of PM.

The development of L-227 was very uniform in both planting dates. Physiological maturity occurred when plants had developed 1 to 2 green pods and 12 to 14 brown pods (table 2). In the field, the number of green pods would be a better visual indicator of PM than the number of brown pods because fewer green pods have to be counted, and because the green pods are on top of the plant. It should be noted, however, that counting green pods would be more difficult if the plants were severely lodged. The development of RAB 205 was more variable between planting dates (table 3 ). On the average, PM of RAB 205 occurred when 2 green pods remained on each plant.

TABLE 2-Coefficients of determination of regression equations for number of green, yellow, and brown pods per plant of two bean genotypes planted in two seasons in Puerto Rico

\begin{tabular}{lcccc}
\hline Genotype & $\begin{array}{c}\text { Planting } \\
\text { date }\end{array}$ & $\begin{array}{c}\text { Green' } \\
\text { pods }\end{array}$ & $\begin{array}{c}\text { Yellow' } \\
\text { pods }\end{array}$ & $\begin{array}{c}\text { Brown' } \\
\text { pods }\end{array}$ \\
\hline L227 & January & 0.92 & 0.52 & 0.96 \\
RAB 205 & May & 0.88 & 0.59 & 0.87 \\
& January & 0.83 & 0.76 & 0.97 \\
May & 0.95 & 0.77 & 0.86 \\
\hline
\end{tabular}

'Linear model.

${ }^{2}$ Quadratic model. 
J. Agric. Univ. P.R. vol. 73, NO. 4, OCTOBER, 1989

TARLE 3.-Estimated number of green, yellow, and brown pods per plant at physiological maturity of two bean genotypes planted in two seasons in Puerto Rico

\begin{tabular}{lccc}
\hline Genotype & $\begin{array}{c}\text { Planting } \\
\text { date }\end{array}$ & $\begin{array}{c}\text { Green } \\
\text { pods }\end{array}$ & $\begin{array}{c}\text { Brown } \\
\text { pods }\end{array}$ \\
\hline L227 & January & 1.5 & 12.3 \\
& May & 1.9 & 14.0 \\
\hline \multirow{3}{*}{ RAB 205 } & Mean & 1.7 & 13.2 \\
& January & 0.1 & 8.2 \\
& May & 4.5 & 8.2 \\
\hline
\end{tabular}

These results show that PM of a community of indeterminate bean plants occurred when most pods were brown; that is, later than the occurrence of PM suggested by other researchers $(2,8,10,11)$. Underestimates of the seed filling period of L227 and RAB 205 would have occurred if previously reported visual indicators for PM had been used. Results from this research indicate that the date when approximately two green pods remain on each plant would coincide with the date of physiological maturity of indeterminate beans.

\section{LITERATURE CITED}

1. CIAT, 1987. Sistema estándar para la evaluación de germoplasma del frijol. Centro Internacional de Agricultura Tropical, Cali, Colombia.

2. CIAT, 1982. Etapas de desarrollo de la planta de frijol común-Guía de estudio. Centro Internacional de Agricultura Tropical, Cali, Colombia.

3. Daynard, T. B. and W. G. Duncan, 1969. The black layer and maturity in corn. Crop Sci. 9: 473-76.

4. Eastin, J. D., J. H. Hultquist and C. Y. Sullivan, 1973. Physiologic maturity in grain sorghum. Crop Sci. 13: 175-78.

5. Fehr, W. R., C. E. Caviness, D. T. Burmood and J. S. Pennington, 1971. Stage of development descriptions for soybeans. Glycine max: (L.) Merrill. Crop Sci. 11: 929-31.

6. —— and 1977. Stages of soybean development. Iowa Agric. Exp. Stn. Special Rep. 80.

7. Garner, J. O., 1976. Some physiological and anatomical aspects of the bean (Phaseolus vulgaris L.) fruit. Ph. D. Thesis. Cornell Univ., Ithaca, NY.

8. Izquierdo, J. A. and G. L. Hosfield, 1983. The relationship of seed filling to yield among dry beans with differing architectural forms. J. Am. Soc. Hort. Sci. 108: 106-11.

9. Steel, R. G. and J. H. Torrie, 1980. Principles and procedures of statistics. McGraw-Hill Co., New York.

10. Lebaron, M. J., 1974. Developmental stages of the common bean plant. Idaho Agric. Exp. Stn. Current Inf. Series 228.

11. Yourstone, K. S., 1988. Photoperiod and temperature interaction effects on time to flower and its components in bean (Phaseolus vulgaris L.). $\mathrm{Ph}$. D. Thesis, Cornell Univ, Ithaca, NY. 